УДК 343.541

DOI https://doi.org/10.32844/2618-1258.2019.6.52

ФІЛЬ І.О.

\title{
ПРОБЛЕМНІ АСПЕКТИ ЗЛОЧИНІВ ПРОТИ СТАТЕВОЇ СВОБОДИ ТА СТАТЕВОЇ НЕДОТОРКАНОСТІ
}

Стаття присвячена злочинам, які посягають на статеву свободу та недоторканість особи, що є одними із найнебезпечніших злочинів Особливої частини Кримінального кодексу України. Порушуючи принципи моралі, вони також посягають не тільки на статеву свободу, недоторканість, але й на інші суспільні відносини, на честь і гідність особи, завдають психологічних і фізичних травм потерпілій.

Злочинах, в яких потерпілим $є$ дитина, мають ще більшу загрозу, оскільки малолітня особа на цей момент знаходиться на етапі свого розвитку й будь-які дії можуть завдати шкоди їх нормальному психічному, фізичному та моральному стану. Розбещення неповнолітніх, статеві зносини з неповнолітнім також можуть викликати певні схилення особи до різних статевих збочень, жорстокості, аморальності. Передчасний вступ може завдати шкоди здоров'ю дитини.

Злочини проти статевої свободи та статевої недоторканості кваліфіковані у VI розділі Особливої частини Кримінального кодексу України: згвалтування (стаття 152 КК України), сексуальне насильство (стаття 153 КК України), примушування до вступу в статевий зв'язок (стаття 154 КК України), статеві зносини 3 особою, яка не досягла 16-річного віку (стаття 155 КК України), розбещення неповнолітніх (стаття 156 КК України).

У статті розкрито поняття «статева свобода» та «статева недоторканість» і різницю між ними. Досліджено деякі проблемні питання, а саме статтю 152 КК України про статеві зносини без добровільної згоди чоловіка $з$ жінкою. Також порівняння санкцій статті 155 КК України «Статеві зносини з особою, яка не досягла 16-річного віку» та статті 156 КК України «Розбещення неповнолітніх». Законодавство не є однаковим протягом років, воно змінюється, перелаштовується під сучасні реалії життя. Дивлячись на це та згідно результатів соціальних опитувань, запропоновано ввезти зміни до вікових обмежень за ч. 4 ст. 152 КК України та ч. 4 ст. 153 КК України, у якій зазначено, що вступ у статеві зносини 3 особою до 14 років карається навіть за наявності добровільної згоди осіб. Також автор зробив аналіз нововведеної санкції ч. 6 ст. 152 КК України та ч. 6 ст. 153 КК України.

Ключові слова: злочини проти статевої свободи та статевої недоторканості особи, особа, суб'єкт, статеві зносини, інтимне життя, статевий акт, партнери, сексуальний контакт.

This article focuses on crimes that infringe upon sexual freedom and inviolability of the person, which are some of the most dangerous crimes of the Special part of the Criminal code of Ukraine. Violating the principles of morality, they also impinge not only on sexual freedom and inviolability, but also in other social relations, honour and dignity of the person, causing psychological and physical trauma of the victim. The crimes of which the victim is a child, have even greater threat, as underage face, at this moment, is in the process of its development, and any action can cause harm to their normal mental, physical and moral condition. Corruption of minors, sexual intercourse with minors, can also cause some inducing a person to various sexual perversions, cruelty, and immorality. Premature introduction may cause considerable harm to the health of the child.

Crimes against sexual freedom and sexual integrity are found in section VI of the Special part of the Criminal code of Ukraine, in which there are: rape (article 152 of the criminal code), sexual violence (article 153 of the criminal code), coercion to sexual intercourse (article 154 of the criminal code), sexual intercourse with a person under

(C) ФІЛЬ І.О. - студент (Національний юридичний університет імені Ярослава Мудрого) 
the age of sixteen (article 155 of the criminal code), corruption of minors (article 156 criminal code).

In the article the concept of "sexual freedom" and "sexual integrity" is the difference between them. Researched some problematic issues, namely article 152 of the criminal code of Ukraine sexual intercourse without voluntary consent of a man with a woman. Compare the sanctions of article 155 of the criminal code "Sexual intercourse with a person under sixteen years of age" and article 156 of the criminal code of Ukraine "Corruption of minors". Legislation is not the same over the years, it changes, rearranges the modern realities of life.

Despite this, and the results of social surveys, it is proposed to bring changes to age restrictions in part 4 of article 152 of the criminal code of Ukraine and part 4 of article 153 of the criminal code of Ukraine, which indicates that engaging in sexual intercourse with person under fourteen years of age is punishable even with the presence of voluntary consent of individuals. And the analysis of the new sanctions part 6 article 152 of the criminal code and section 6 of article 153 of the criminal code of Ukraine.

Key words: crimes against sexual freedom and sexual integrity of a person, person, subject, sexual intercourse, intimate life, sexual intercourse, partners, sexual contact.

Вступ. Відповідно до Основного Закону та низки міжнародних актів людина, iї життя i здоров'я, честь і гідність, недоторканність і безпека визнаються найвищою соціальною цінністю. Злочини проти статевої свободи й недоторканності особи пов'язані з грубими порушеннями норм суспільної моралі, особистої свободи та недоторканості особи, тому Особливою частиною закону про кримінальну відповідальність за них передбачено сувору відповідальність.

Після підписання Україною Конвенції Ради Свропи про запобігання насильству стосовно жінок і домашньому насильству та боротьбу з цими явищами (далі - Стамбульська конвенція) спеціальним законом від 06.12.2017 № 2227-VIII було внесено зміни й КК України з метою реалізації положень цього міжнародного акту [5]. Внесення цих змін викликало жваве обговорення і в науковій спільноті. Реформа кримінальної відповідальності за «статеві злочини» хоч і $є$ доцільною та відповідає вимогам часу, проте не позбавлена низки істотних недоліків.

Постановка завдання. Метою статті $є$ дослідження злочинів проти статевої свободи та статевої недоторканості, висвітлення певних складнощів і проблем їх застосування.

Результати дослідження. Проблематика злочинів проти статевої свободи та статевої недоторканості особи є досить актуальною для розвинених країн. Останні зміни Кримінального кодексу України, метою яких було охопити всі суспільні проблеми злочинів сексуального характеру, дали значний поштовх національному законодавству для встановлення гендерної рівності жінок і гармонізації законодавства України з міжнародно-визнаними зразками, враховуючи положення Стамбульської конвенції. Зважаючи на існуючі реалії сексуальних стосунків виникає потреба в додатковій увазі з боку держави як гаранта прав і свобод людини шляхом врегулювання відносин між людьми та визначення межі, коли нормальні суспільні відносини приватно-інтимного характеру переростають у протиправне, кримінально каране посягання на статеву недоторканість і свободу.

Для того, щоб говорити про злочини проти статевої свободи та статевої недоторканості, спочатку потрібно з'ясувати, про що йдеться, що таке «статева свобода» та «статева недоторканість». Під злочинами проти статевої свободи розуміють певні умисні дії суб'єкта злочину проти статевої свободи та недоторканості іншої особи, які знаходяться під охороною кримінального права, що порушують встановлений у суспільстві уклад статевих відносин та основних принципів моральності.

Статева свобода - це право особи самостійно обирати собі партнера для статевих зносин та їх форму, а також не допускати будь-якого примусу від одного із партнерів. Якщо статева свобода - можливість самостійно розпоряджатися своїм інтимним життям без втручання інших, то статева недоторканість - це стан особи, який знаходиться під охороною закону, що забороняє будь-які дії сексуального характеру з особою, яка не є носієм статевої свободи. Прикладом цього є особи, які не досягли відповідного віку, мають психічну хворобу, тобто, ті особи, які потребують додаткового захисту від держави в силу своєї неспроможності захистити себе самостійно [6].

Із внесенням змін до КК України було вирішено багато питань, пов'язаних із домашнім насильством стосовно жінок (і не тільки), закріплених у положеннях Стамбульської Конвенції в частині боротьби з гендерною дискримінацією. Але й наразі є деякі прогалини в законодавстві. 
Відповідно до ч. 1 ст. 152 КК України згвалтуванням вважається «вчинення дій сексуального характеру, пов'язаних із вагінальним, анальним або оральним проникненням в тіло іншої особи з використанням гені талій або будь-якого іншого предмета без добровільної згоди потерпілої особи» [1]. Виходячи з тексту статті, суб'єкт, який вчиняє злочин щодо статевої свободи та недоторканості, проникає в тіло потерпілої особи способом і предметами, передбаченими статтею. Щодо способів орального та анального проникнення питань не виникає, але щодо вагінального постає питання. Чи підпадають під кримінальну відповідальність дії жінки проти статевої свободи чоловіка з використанням вагінального проникнення за допомогою геніталій потерпілого? Статтею буквально передбачено лише протилежний випадок, коли чоловік або жінка здійснює проникнення у вагіну жінки-потерпілої. Звідси виникають сумніви щодо дотримання гендерного балансу в частині однакової охорони статевої свободи чоловіків і жінок.

За буквального тлумачення вчинення жінкою дії сексуального характеру з особою чоловічої статі (в тому числі й неповнолітньої), пов'язаної з вагінальним проникненням за допомогою геніталій потерпілого, не буде вважатися згвалтування. Натомість такі дії охоплюватимуться статтею 153 КК («Сексуальне насильство), яка передбачає менш сувору відповідальність. На думку автора, для подолання вказаного недоліку необхідно словосполучення «в тіло іншої особи» замінити на словосполучення «в тіло людини» або «в тіло особи». У такому випадку не будуть виникати сумніви у дотриманні гендерного балансу.

Одним із провідних напрямів сучасної світової політики $є$ також соціально-правовий захист дітей. Він $є$ показником рівня розвитку, цивілізованості та перспективності. Статеві злочини проти дітей $є$ особливо небезпечними, оскільки вони в подальшому впливають на свідомість і світосприйняття майбутнього покоління. Діти - це особи, які вимагають більшого захисту зі сторони держави в силу своєї неспроможності захистити себе, а інколи й нерозуміння того, що відбувається.

У КК Україні наразі виділено дві окремі статті щодо осіб, які не досягли 16-річного віку. Це стаття 156 КК України («Розбещення неповнолітніх») та стаття 155 КК України («Статеві зносини з особою, яка не досягла 16-річного віку») [1]. Конкретизованого визначення «розбещення неповнолітніх» в українському законодавстві не встановлено, але існує багато правових думок щодо його визначення. Проаналізувавши їх можна дійти висновку, що поняття «розбещення неповнолітніх» передбачає собою розпусні дії сексуального характеру без проникнення, зловживання владою дорослих або підлітків, які шляхом примушення або обману намагаються вступити 3 неповнолітніми у сексуальний контакт для задоволення статевої пристрасті особи, яка їі здійснює, так і на задоволення такої пристрасті інших осіб, якщо дії здійснюються у їхній присутності, чи розпалювання статевого інстинкту в неповнолітньої особи[7].

За об'єктивною стороною статеві зносини з проникненням в тіло особи є більш тяжким злочином. Санкції 155 і 156 статей КК України є абсолютно ідентичними як щодо розбещення, так і щодо згвалтування. Чи правильно законодавець встановив однакову відповідальність за ці злочини? Чому за два злочини різної тяжкості, що спричиняють різні наслідки (у статті 155 КК України - відповідний емоційний стан, безплідність чи інші тяжкі наслідки; за статтею 156 КК України - емоційний стан) одна і та сама відповідальність? За частиною 1 статті 155 КК України санкція повинна бути більшою в силу більш істотного ступеня суспільної небезпечності зносин порівняно з розбещенням за частиною 1 статті 156 КК.

Суспільство не стоїть на місці, воно змінюється, тому законодавство для врегулювання суспільних відносин повинно трансформуватися під нього. За даними опитувань 17-річної молоді, в якої вже був перший досвід інтимного життя, було виявлено, що практично кожен десятий підліток, який мав статеві зносини, визнав віком сексуального дебюту 12 років і молодше (12,1\% юнаків і $3,5 \%$ дівчат) [8].

Згідно з частиною 4 статті 152 «вчинення дій сексуального характеру, пов'язаних із вагінальним, анальним або оральним проникненням у тіло іншої особи 3 використанням геніталій або будь-якого іншого предмета, вчинені щодо особи, яка не досягла 14 років, незалежно від ії добровільної згоди, карається законом від 10 до 15 років позбавлення волі» [1], аналогічно з частиною 4 статті 153 КК. У зв'язку з цим виникає проблема оцінки «добровільних» статевих зносин, коли обоє партнерів не досягли 14-річного віку. Де-факто (у практичному вимірі) такі діяння навряд чи будуть якось переслідуватися, хоча згідно закону є суспільно небезпечними. Разом із тим статевий зв' язок (у тому числі «добровільний») 14-річної особи з 13річною автоматично стає злочином. Чи є це справедливим і гуманним? Можливо, потрібно передбачити інші умови щодо цього віку та включити відсутність добровільної згоди як одну з умов згвалтування. 
Враховуючи постійне пришвидшення розвитку сучасних підлітків, у порядку de lege ferenda буде доцільним включення додаткових умов щодо добровільної згоди таких осіб. Першою 3 них $є$ психологічна зрілість особи, ії ставлення, бажання та розуміння того, що відбувається. Також повинно враховуватися інтимне життя особи: чи були статеві зв'язки між ними до вчинення «злочину»? Другою умовою є психічне здоров'я особи до і після статевого акту. Але для забезпечення захисту цих осіб слова «потерпілої» повинні мати пріоритет над словами кривдника як і особа, що не досягла 14-річного віку, потребує більшого захисту в силу своєї необізнаності. Тому при відсутності хоча б однієї з умов добровільна згода має виключатися.

Нещодавно до КК України Законом України «Про внесення змін до деяких законодавчих актів України щодо впровадження Єдиного реєстру осіб, засуджених за злочини проти статевої свободи та статевої недоторканості малолітньої особи, та посилення відповідальності за злочини, вчинені проти статевої свободи та статевої недоторканості малолітньої особи» 19 грудня 2019 року були внесені зміни [3]. Хотілося б звернути увагу на доповнення до статей 152 і 153 КК України шостими частинами, згідно з якими згвалтування та сексуальне насильство щодо малолітніх, вчинені повторно або особою, яка раніше вчинила будь-який із злочинів, передбачених частиною 4 або 5 статті 153, статтею 155 або частиною 2 статті 156 цього Кодексу, караються позбавленням волі на строк 15 років або довічним позбавленням волі.

В санкції відсутня інша альтернатива, індивідуальна визначеність за кожен конкретний злочин. Одним із головних принципів кримінального права є принцип індивідуалізації кримінальної відповідальності і покарання, який полягає у тому, щоб кримінальна відповідальність і призначене покарання були максимально конкретизовані та індивідуалізовані з огляду на конкретні обставини вчиненого злочину та з урахуванням особи винного. Тобто, за вчинений особою злочин покарання має бути індивідуалізоване з урахуванням об'єктивної сторони, особи винного, обставин, які обтяжують чи пом'якшують відповідальність, наслідків та іншого. Частина 6 статті 152 та частина 6 статті 153 КК України порушують цей принцип.

Порушується також принцип гуманізму. Це ще один не менш значущий принцип, викладений у статті 3 Конституції України: «Людина, ії життя і здоров’я, честь і гідність, недоторканність і безпека визнаються в Україні найвищою соціальною цінністю. Права і свободи людини та їх гарантії визначають зміст і спрямованість діяльності держави. Держава відповідає перед людиною за свою діяльність. Утвердження і забезпечення прав і свобод людини є головним обов'язком держави» [4].

Принцип гуманізму визначає те, що покарання особи, визнаної винною у вчиненні злочину, не повинно мати на меті завдання їй фізичних страждань або приниження людської гідності. У разі призначення покарання особі, яка вчинила злочин, воно повинно бути необхідним і достатнім для його виправлення особи та попередження нових злочинів. Не можливо встановити якогось відповідного, конкретного строку для виправлення всіх винуватих за конкретний злочин. Кожному злочинцю повинно бути призначено індивідуальне покарання, яке буде сприяти саме його виправленню. Визначення такого строку буде негуманним до винних, тому необхідно встановити певні межі: найнижчу та найвищу. Наприклад від 12 до 15 років позбавлення волі або довічне позбавлення волі. Або можна зробити виключення із правил призначення покарання та встановити санкцію від 12 до17 років позбавлення волі чи ж довічне позбавлення волі.

Висновки. 3 внесенням змін до Кримінального кодексу України щодо злочинів проти статевої свободи та статевої недоторканості було вирішено низку питань щодо захисту жінок від домашнього насильства, підвищено захист статевої свободи і недоторканості особи, особливо щодо малолітніх осіб. Разом із тим реформа кримінального закону в частині кримінальної відповідальності за «статеві злочини» супроводжується сукупністю істотних недоліків, які потребують свого вирішення.

\section{Список використаних джерел:}

1. Кримінальний кодекс України : Закон України від 5 квітня 2001 року № 2341-III зі змінами і доповненнями станом на 13.03.2020. URL: https://zakon.rada.gov.ua/laws/show/2341-14 (дата завершення: 13.03.2020).

2. Дудоров О.О. Злочини проти статевої свободи та статевої недоторканості особи (основні положення кримінально-правової характеристики) : практ. порадник. Северодонецьк : РВВ ЛДУВС ім. Е.О Дідоренка, 2018. Ст. 92.

3. Про внесення змін до деяких законодавчих актів України щодо впровадження Єдиного реєстру осіб, засуджених за злочини проти статевої свободи та статевої недоторканості ма- 
лолітньої особи, та посилення відповідальності за злочини, вчинені проти статевої свободи та статевої недоторканості малолітньої особи : Закон України 19 грудня 2019 року № 409-IX. URL: https://zakon.rada.gov.ua/laws/show/409-20 (дата звернення: 13.03.2020).

4. Конституція України : Закон України від 28 червня 1996 року зі змінами. URL: https://zakon.rada.gov.ua/laws/show/254к/96-вр (дата звернення: 13.03.2020).

5. Про внесення змін до Кримінального та Кримінального процесуального кодексів України з метою реалізації положень Конвенції Ради Свропи про запобігання насильству стосовно жінок і домашньому насильству та боротьбі з цими явищами : Закон України від 06.12.2017 № 2227-VIII. URL: https://zakon.rada.gov.ua/laws/show/2227-19\#n63 (дата звернення: 13.03.2020).

6. Марина Хоменко. Злочин проти статевої свободи і статевої недоторканості особи: особливості законодавчого врегулювання сьогодення. Підприємство, господарство і право, 2018. URL: http://pgp-journal.kiev.ua/archive/2018/11/40.pdf (дата звернення: 13.03.2020).

7. Авраменко С.М. Дисертація розслідування розбещення неповнолітніх. Національна академія внутрішніх справ, 2017. Ст. 242 (дата звернення: 13.03.2020).

8. Коли українські підлітки починають займатися сексом: дослідження. Українська правда, 22 травня 2019. URL: https://life.pravda.com.ua/health/2019/05/22/236984/ (дата звернення: 13.03.2020). 